OPEN ACCESS

Edited by:

Hsin-I. Chang,

University of Arizona, United States

Reviewed by:

Andreas Panagopoulos, Institute of Soil and Water Resources (ISWR), Greece Asghar Azizian, Imam Khomeini International University, Iran

*Correspondence:

M. Dinesh Kumar dineshcgiar@gmail.com

Specialty section: This article was submitted to Water and Hydrocomplexity, a section of the journal

Frontiers in Water

Received: 01 February 2021 Accepted: 25 May 2021

Published: 21 June 2021

Citation: Kumar MD and Bassi N (2021) The Climate Challenge in Managing Water: Evidence Based on Projections in the Mahanadi River Basin, India. Front. Water 3:662560. doi: 10.3389/frwa.2021.662560

\section{The Climate Challenge in Managing Water: Evidence Based on Projections in the Mahanadi River Basin, India}

\author{
M. Dinesh Kumar ${ }^{1 *}$ and Nitin Bassi ${ }^{2}$ \\ ${ }^{1}$ Institute for Resource Analysis and Policy, Hyderabad, India, ${ }^{2}$ Institute for Resource Analysis and Policy, Liaison Office, \\ New Delhi, India
}

This study analyzes the long-term changes in the rainfall and surface hydrology of the upper and middle sub-basins of Mahanadi, an inter-state river basin in eastern India that experiences climate-induced hydrological extremes, and draws implications for the sustainability of irrigation and drinking water supplies. The likely impacts of rainfall changes on surface flow were also modeled. A Water Evaluation and Planning (WEAP) model was set up (beginning June 2009 and ending May 2050) to analyze the future water balance of the basin for the expected changes in socio-economic conditions. The model was also run for future scenarios that considered different water management interventions, and hydrological consequences of climate variability and change. The model results showed that there would be a water deficit, about 2,182 million cubic meters (MCM) by 2050 (20\% of the demand) even under the business-as-usual scenario. The gap is expected to widen to 5,005 MCM (25\% of the demand) under a high growth scenario. Further, the water demand management interventions in agriculture would be able to reduce the overall demand for water in the basin to some extent, while it would also reduce the supplies slightly due to a reduction in return flows occurring as a result of irrigation efficiency improvement. The water deficit under this scenario will reduce to about 2,773 MCM in 2050. Under the predicted changes in climate, the water deficit is expected to reduce further (will be 1,684-2,373 MCM in 2050) due to an increase in supplies owing to an increase in the catchment yields resulting from higher rainfall. While there will be a significant amount of outflow from the two sub-basins in all the scenarios in most future years (ranging from 25,286 MCM to 28,697 MCM in 2050), during drought years, the water deficit in the upper basin areas will increase slightly, but with a significant reduction in the outflows to the lower sub-basin areas by 2046-47 (will be about $11,311 \mathrm{MCM}$ ). These results indicate that there is a need for building more water storage/diversion infrastructure to detain floodwaters during wet years that can provide buffer storage for the dry years.

Keywords: climate variability and change, climate extremes, WEAP, water balance, water deficit 


\section{INTRODUCTION}

Climate variability and climate change have challenged the way water resources need to be managed, especially in developing countries that are struggling to keep pace with the increasing consumptive and environmental demands for water on the one hand and deterioration of water quality on the other. The uncertainty in the rainfall patterns (intensity and duration) has resulted in the occurrence of extreme hydrological events, such as severe floods and hydrological droughts with greater frequency causing significant socio-economic damages (Batisani and Yarnal, 2010; Zhang et al., 2013; Marengo and Espinoza, 2016). In regions characterized by the frequent floods and droughts due to hydrological extremes and those that witness imbalances between water availability and demand at the aggregate level, the impacts of climate change on water resources will be more pronounced (Estrela et al., 2012).

India experiences substantial inter-annual and inter-regional variations in rainfall, annual potential evaporation rates, relative humidity, temperature, and wind speed (Mall et al., 2006; Khan et al., 2009; Davis et al., 2019; Kumar et al., 2021). Together, they can induce major changes in the physical and biophysical processes (Singh and Kumar, 2015). For instance, regions that receive high solar radiation, low rainfall, but experiencing low relative humidity and high temperature will require a much larger quantum of water for raising crops than what is required by the same crops if grown in a cold region, experiencing high rainfall and relative humidity and low solar radiation. Also, more water will be lost through evaporation from water bodies and soils in hot and arid regions as compared to cold and humid regions (Kumar et al., 2021). Also, annual renewable water availability will vary both spatially and temporally depending on the magnitude of rainfall (Gosain et al., 2011). The water availability and demand will further be influenced by the changes in rainfall trends and patterns and seasonal evaporation (Konapala et al., 2020). Regions where water availability will be adversely impacted due to the frequent droughts, an increase in water demand for non-agricultural purposes (for instance urban domestic and industrial uses) will bring in a new set of challenges related to water management (Xiong et al., 2010). Therefore, understanding the impact of "climate variability" on water resource availability and water demand would help understand the likely temporal impact of the change in climate on the hydrological system and water resources (Kumar et al., 2021).

One such basin that is facing the challenges posed by climate-induced hydrological extremes is the Mahanadi, a transboundary (inter-state) river basin in eastern India. The basin is divided into three segments, viz., upper, middle, and lower Mahanadi and has a total drainage area of 140,000 sq. km (Figure 1). The catchment area of the basin extends over major parts of Chhattisgarh and Odisha states, constituting about 52 and $47 \%$ of the basin area, respectively. Very small proportions of the basin's drainage area also fall in Jharkhand $(0.1 \%)$, Maharashtra (0.23\%), and Madhya Pradesh (0.1\%). The basin is divided into 11 elevation zones, the maximum observed is $1,321 \mathrm{~m}$ in the steep hilly terrain, and the minimum is $10-50 \mathrm{~m}$ in the deltaic stretch (CWC and NRSC, 2014).
The major part of the basin area receives $1,200-1,400 \mathrm{~mm}$ of rainfall (with some parts recording nearly $1,600 \mathrm{~mm}$ of rainfall) with an average annual basin rainfall of about $1,292 \mathrm{~mm}$. The mean annual runoff of the basin is about 67 billion cubic meters (BCM). As per official estimates, the basin has a total surface water storage capacity of $14.24 \mathrm{BCM}$, just $21.2 \%$ of the mean annual runoff. It has a total of 74 irrigation and five hydroelectric projects, out of which 63 projects are completed and 11 are on-going. Hirakud and Hasdeo Bango with a gross storage capacity of 8.14 and $3.42 \mathrm{BCM}$, respectively, are the biggest storage reservoirs (CWC and NRSC, 2014). A large proportion of the surface water in the basin remains un-tapped. The utilizable groundwater resource of the basin is about 16.5 BCM (Kumar and Bassi, 2017). The Central Water Commission (CWC), a premier national level agency concerned with water resources development planning in India, maintains 39 gaugedischarge sites in the basin. Out of these, sediment observations are also made in 13 stations. Further, the CWC maintains four flood forecasting stations in the basin. There are about 1,147 groundwater observation wells in the whole basin (CWC and NRSC, 2014).

There is a high year to year variability in the basin yield (runoff) and the river discharge into the ocean. While floods occur during the wet years in the lower Mahanadi sub-basin, water scarcity is prevalent during dry years across the basin. Further, with rapidly growing economic activities, manifested by rapid industrialization and urbanization in the riparian states viz., Chhattisgarh and Odisha and an annual compounded population growth of $3.3 \%$, the water resources of the basin would come under enormous stress in future, with magnified stress during droughts (Kumar and Bassi, 2017). This can lead to conflicts over allocation of water within as well as between states. In the event of climate change with the higher frequency of extreme events, the challenges will be great.

With this background, the objective of this paper is to analyze the long-term changes and inter-annual variability in the rainfall and surface hydrology of the upper and middle sub-basins of Mahanadi, and draws implications for the sustainability of irrigation and drinking water supplies. The upper and middle sub-basins contribute to the inflows into Hirakud reservoir which is one of the biggest storage reservoirs in India and an important infrastructure for ensuring water security in the Mahanadi basin. The study was undertaken for the upper and middle sub-basins of the Mahanadi River.

\section{METHODOLOGY AND ANALYTICAL TOOLS}

The methodology involved a combination of water balance modeling study of the upper and middle part of the Mahanadi basin (using Water Evaluation and Planning System) and several tailor-made analytical tools for estimating the characteristics of various parameters that define the basin hydrology. The water balance provides an estimate on the water availability, water requirement, and water supply for a given year that helps in determining whether the basin is in water surplus or is in deficit (Bassi et al., 2020). The following analyses were undertaken: 


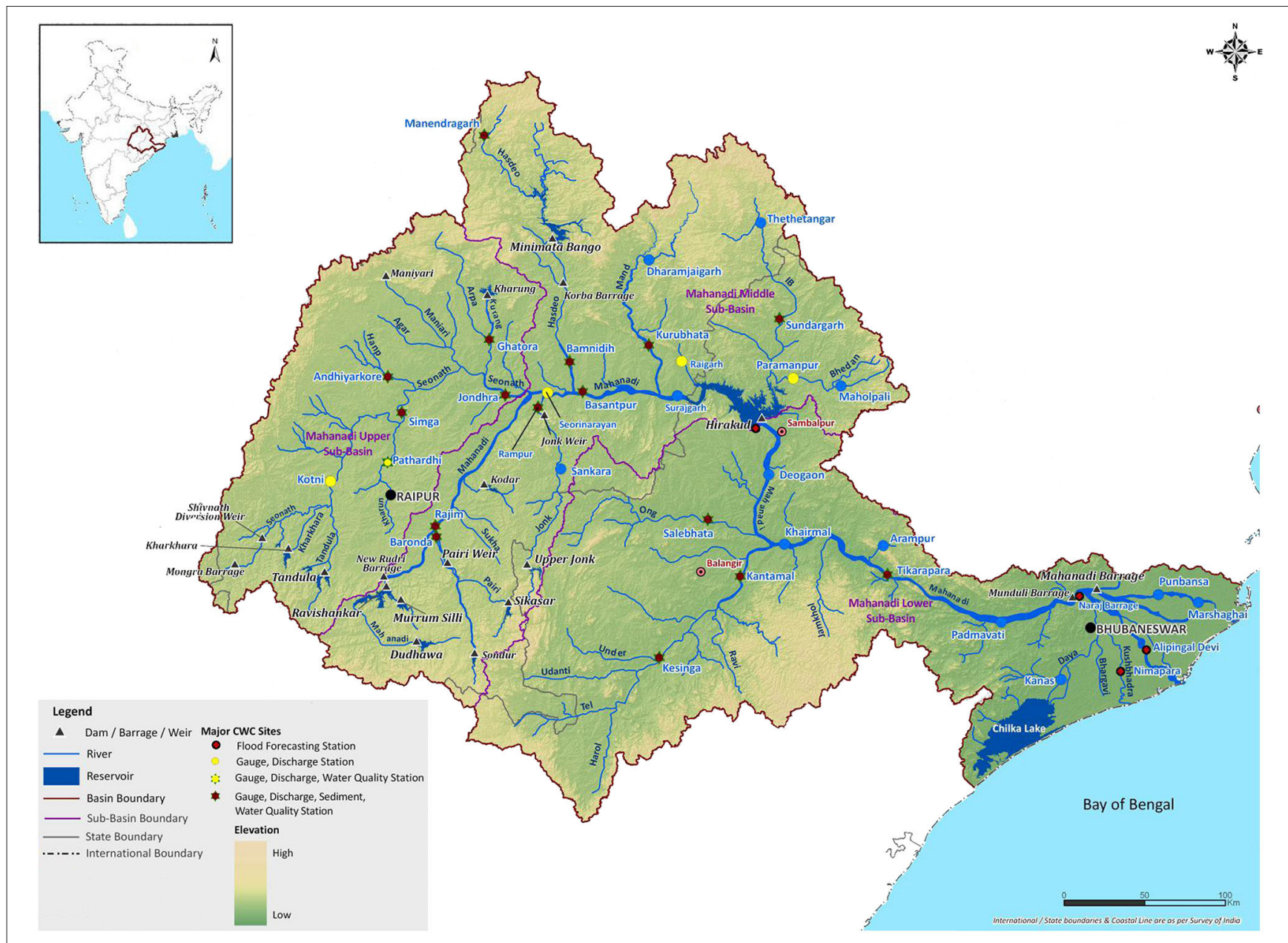

FIGURE 1 | Drainage -basins of Mahanadi River. Source: CWC and NRSC (2014).

\section{Analysis of Rainfall as a Climate Variable in the Basin}

Rainfall is one of the important climate variables that can have a significant impact on water resources of the basin through alterations in runoff and recharge and soil moisture storage, as the basin has a limited groundwater stock owing to unique geology. Most of the upper and middle part of the basin is underlain by hard rocks that have limited groundwater storage capacity and thus negligible static groundwater resources. Owing to these unique characteristics of hard rock aquifers and the steep groundwater flow gradients, a substantial amount of annual recharge discharges into the river as baseflow. While increase in the magnitude of rainfall can increase the catchment runoff, for the same magnitude of rainfall, an increase in intensity with no major change in the duration of dry spells can also increase the runoff (depending on the value of soil infiltration capacity in relation to the intensity of rains), whereas the quantum of recharge will be adversely affected (Kumar et al., 2021). To understand the past trends in rainfall in the study area, daily rainfall data (from 1975 to 2015) from the seven rain-gauging stations were collected from the water resources department of the riparian states and a detailed analysis was undertaken with the total magnitude of annual rainfall, and annual rainy days. The types of analysis included the following: (i) estimation of the coefficient of variation in the rainfall and rainy days, indicative of inter-annual variability, using historical data; (ii) estimation of long term trends in rainfall and rainy days using Mann-Kendall analysis (a non-parametric test that works for all types of data distribution) to understand the nature of the trend, the slope, and the significance; and, (iii) the relationship between rainfall and the pattern of occurrence of rains in terms of rainy days.

\section{Estimation of Basin's Dependable Yield}

For optimal utilization of the surface water resources, there is a need for developing a clear understanding of the catchment characteristics, current land use in the catchment, and the hydrological regime. Of particular interest are the current streamflow regimes, the extent of base flow contribution to the stream flows, and the geological and geo-hydrological environment of the catchment (Kumar, 2010; IRAP, 2015). 
Several methods and tools are available for catchment assessment and catchment management planning (James et al., 2015; Kumar et al., 2019). One such method, which is appropriate for the current study, is the development of an empirical model for the relationship between rainfall and runoff within a catchment (Kumar et al., 2019). It captures the effect of various hydrological processes such as rainfall, its pattern of occurrence, soil infiltration, soil evaporation, and evapotranspiration (ET) together determining the runoff.

The rainfall-runoff model was built for the hydraulically independent catchments in the two sub-basins and the total yield was arrived at. For this, two river gauging sites having no large water diversion infrastructure in their upper catchments were identified for each sub-basin. The observed flows from each such gauging site were considered to be virgin flows from the catchment, which is the runoff that would occur from the catchment in the event of no artificial impoundments. For the two selected catchments in the upper sub-basin, the stream-flow data was available from $1978-79$ to $2010-11$ and $1989-90$ to 2010-11, respectively. For the sites in the middle sub-basin, it was available for the period from 1978-79 to 2011-12 and 198990 to 2010-11, respectively. This data was collected from the CWC. The time series data of the annual rainfall for various rain-gauging stations maintained by the Indian Meteorological Department (IMD) in the two sub-basins was collected for the period from 1971 to 2004 for both the sub-basins.

Using the estimated streamflow series, and the weighted average of the annual rainfall, the rainfall-runoff relationship was established using regression analysis. The regression used the annual stream flows (for each hydrological year) against the rainfall of the catchment for the corresponding years, instead of monthly flows, as the base flow contribution to the monthly runoff were expected to be significant. The regression equation which gave the best fit was chosen as the rainfall-runoff relationship for the catchment/basin.

The rainfall-runoff model so constructed was used to generate the annual runoff data for the previous years for which stream gauging data were not available. Further, the estimated streamflow series and the observed flows were used to estimate the $(75 \%)$ dependable flows by estimating the "probability of exceedance" (or the minimum amount of flows that would occur with $75 \%$ dependability). This was treated as the dependable yield of the basin. Also, this model was used to predict future changes in the runoff in the basin, caused by likely changes in climate, using the predicted values of rainfall for different points of time in the future. The total renewable groundwater resource of the study area was estimated using the block-wise data from the Central Groundwater Board (CGWB) following the apportionment method. The estimates of renewable surface water and groundwater were added to arrive at the sustainable yield of the catchment.

\section{Estimating Current Water Use}

The consumptive water use was estimated for the agriculture, urban and rural domestic, livestock, and industrial sectors. As regards agriculture, the current water use in irrigated crops (including those which are given supplementary irrigation) was estimated using the FAO CROPWAT model based on data on growing season and date of sowing and harvesting for each of the agro climates prevailing in the region for which model data were available (Smith, 1992). The model generates data on potential evapotranspiration (PET) and effective rainfall. The difference between PET and effective rainfall gave the irrigation requirement. An allowance of $15 \%$ was applied for taking care of the non-beneficial evaporation (E) and non-recoverable deep percolation (DP) of water (refer Allen et al., 1997 and Kumar and van Dam, 2013 for the description of non-beneficial $\mathrm{E}$ and non-recoverable DP). The total current irrigation water use in agriculture was estimated based on the irrigated area under different crops (ha) in different seasons and the water consumption rate in irrigation $(\mathrm{mm})$.

Water use in the urban domestic sector was estimated based on the norms on per capita water supply for different categories of urban areas, ranging from 70 liters per capita day (lpcd) for households (HHs) in towns with piped water supply but without sewerage connection to $150 \mathrm{lpcd}$ for $\mathrm{HHs}$ in cities with a piped water supply and sewerage connection (CPHEEO, 1999), and population of the urban area. Rural domestic water use was estimated using the same procedure, wherein the per capita water supply norm for rural areas (which is $55 \mathrm{lpcd}$ ) was used.

In the case of livestock, the population of different types of livestock, the recommended per capita voluntary water consumption per Livestock Unit for different types of livestock, and the Total Livestock Units (TLU) for the animal under consideration, for the prevailing climatic conditions (based on Pallas, 1986) of the area was used.

To estimate the current industrial water consumption per annum, the total amount of industrial outputs under each category of the industry in the basin (ton per annum), and the data on water intensity of industrial production for different categories of industries such as cement, pharmaceuticals, chemicals, textile, and steel was used (GOI, 1999).

\section{Estimating Water Supplies for Meeting the Demands}

In the case of surface reservoirs, the total storage capacity (dead and live storage), the discharge capacity of the off-taking canals, and the reservoir operation rules were used. Further, to estimate the evaporation losses from the reservoirs, the storage elevation area (SAE) curve of each reservoir was used. Using the figures of the total amount of water impounded in the reservoirs, and the SAE (storage-area-elevation) curves, and PE for the area (based on computed values of daily reservoir evaporation available from the reservoir mass balance), the evaporation was computed by the Water Evaluation and Planning (WEAP) model. The water supply potential of barrages was estimated by the discharge capacity of the off taking canals and pipelines. In the case of groundwater, the total water supply capacity of the existing system was estimated by using the annual data on the total groundwater stock and the annual recharge. The data was obtained from the CGWB. 


\section{Estimating Future Water Demands}

The future water demands in the basin, i.e., for 2020, 2030, and 2050 , in various sectors were estimated considering the potential drivers. Since the demand for water in agriculture (crops and livestock) would grow in proportion to the growth in irrigated area and the livestock, it was estimated using the compound annual growth rate (CAGR) for 5 years (2010-11 to 2014-15 for the area under irrigation and the period of 2007-2012 for the livestock). Further, it was considered that the population would drive water demand in the domestic sector, at the same rate at which it would grow in the future. The likely future population growth rate in the study area was estimated by taking the average of the annual compounded growth rate in population during the past four decades (1971-2011) separately. The projections were done separately for rural and urban areas. Similarly, industrial growth would drive the demand for water in that sector in proportion to the growth in industrial outputs, unless measures are introduced for efficiency improvements. For estimating the industrial water demand, the industrial growth rate during the 5 years (2011-2016) was used for all sub-sectors across the board.

\section{Climate Change and Other Scenarios for the Basin}

The WEAP model was used for building the future water balance scenarios. For calibration and validation of the model, the observed monthly river discharge data for 23 years (19892011) was used. To analyze the impact of various water management interventions for the basins, the "business as usual" scenario of water balance for the future (with the socio-economic changes such as population growth, agricultural expansion, urbanization, and industrial growth as discussed in section Estimating Future Water Demands) assuming climate as constant, were compared against the water balance scenarios with various suggested interventions and with climate change as an over-arching driver.

For generating water balance scenarios under climate change, the rainfalls and temperature predicted by climate models for the basin or region were used to compute the runoff and ET for the basin, respectively. For this, the results available from the climate modeling carried out by IITM-Pune and Hadley Centre for Climate Prediction and Research using the Hadley Centre Regional Climate Models, and the historical trends in rainfall were used. The model was set up for the South Asian domain and run to simulate the climate for the past (19611990) and a future time periods (2071-2100). It incorporated two different socioeconomic scenarios, both characterized by regionally focused development but with priority to economic issues in one (referred to as A2) and to environmental issues in the other (referred to as B2). The water balance scenario for years of extreme climate events such as droughts was also examined.

A high growth driven water demand, and water use efficiency improvement plan for agriculture were the two other scenarios that were simulated in the model for estimating the future water balance. The demand-supply gap was evaluated for each scenario.
TABLE 1 | Analysis of point rainfall of seven locations in the study area.

\begin{tabular}{lcccc}
\hline Rain gauge stations & Mean (mm) & CV (\%) & Maximum (mm) & Minimum (mm) \\
\hline Admabad & 959 & 29.5 & 1,529 & 453 \\
Dararikorba & 1,436 & 27.3 & 2,579 & 590 \\
Janjgir & 1,233 & 22.2 & 2,116 & 813 \\
Khutaghat & 1,162 & 24.8 & 1,831 & 663 \\
Moorumsilli & 1,239 & 23.5 & 1,999 & 611 \\
Raigarh & 1,213 & 30.7 & 2,039 & 635 \\
Rudri & 1,253 & 24.1 & 2,149 & 721 \\
\hline
\end{tabular}

Source: Authors' own analysis using IMD data.

\section{RESULTS AND FINDINGS}

\section{Rainfall Analysis}

The long-term annual mean rainfall is 1,300-1,250 millimeters $(\mathrm{mm})$ in the upper and middle sub-basins, respectively. The average annual rainfall varies from 888 to $1,988 \mathrm{~mm}$ in upper, and 861 to $1,739 \mathrm{~mm}$ in middle sub-basins.

To understand the variability in rainfall and rainfall pattern, and change in rainfall and rainfall pattern over time in the study area, daily rainfall data of seven gauging stations for 41-year period (1975-2015) in the two sub-basins were analyzed (refer to Table 1). As per the analysis, the mean values vary from the lowest of $959 \mathrm{~mm}$ (Admabad) to $1436 \mathrm{~mm}$ (Dararikorba). The coefficient of variation in rainfall varies from a lowest of $22.2 \%$ (Janjgir) with a mean annual rainfall of $1233 \mathrm{~mm}$ to a highest of $30.7 \%$ (Raigarh), with a mean annual rainfall of $1,213 \mathrm{~mm}$. In the case of Dararikorba, the difference between the maximum and minimum rainfall was around $1990 \mathrm{~mm}$, which is far higher than the mean annual rainfall recorded in that location.

In four out of the seven locations, rainfall showed a declining trend, and in the rest three, the trend is ascending one. However, only in one (Rudri) out of the four cases where there is a declining trend in the rainfall, it is statistically significant with the MannKendall $Z$-value nearly becoming -1.96 (refer to Figure 2 ). The average decline in rainfall is nearly $7.1 \mathrm{~mm}$ per year, based on 41 year data (1975-2015). In cases where the annual rainfall values showed ascending trends, the trend is not statistically significant.

As regards the rainfall pattern, the number of rainy days varies from a lowest of 51 (Admabad) to a highest of 80 (Dararikorba), the latter location having recorded the highest mean annual rainfall. The coefficient of variation in rainy days varies from a lowest of 17 (for two locations) to a highest of 34 (Khutaghat), the latter receiving rainfall for 54 days (refer to Table 2). Here, the locations which correspond to low mean annual rainfall also have rainfall occurring in fewer rainy days, and vice versa. For instance, Admabad has the lowest mean annual. It also recorded the lowest number of mean annual rainy days. Dararikorba which recorded the highest (mean) annual rainfall also has rainfall occurring in the largest number of days. Therefore, there is strong correlation between rainfall and rainy days. The regression analysis showed a good correlation between rainfall and rainy days in four out of the seven locations, with the $R$-square value 


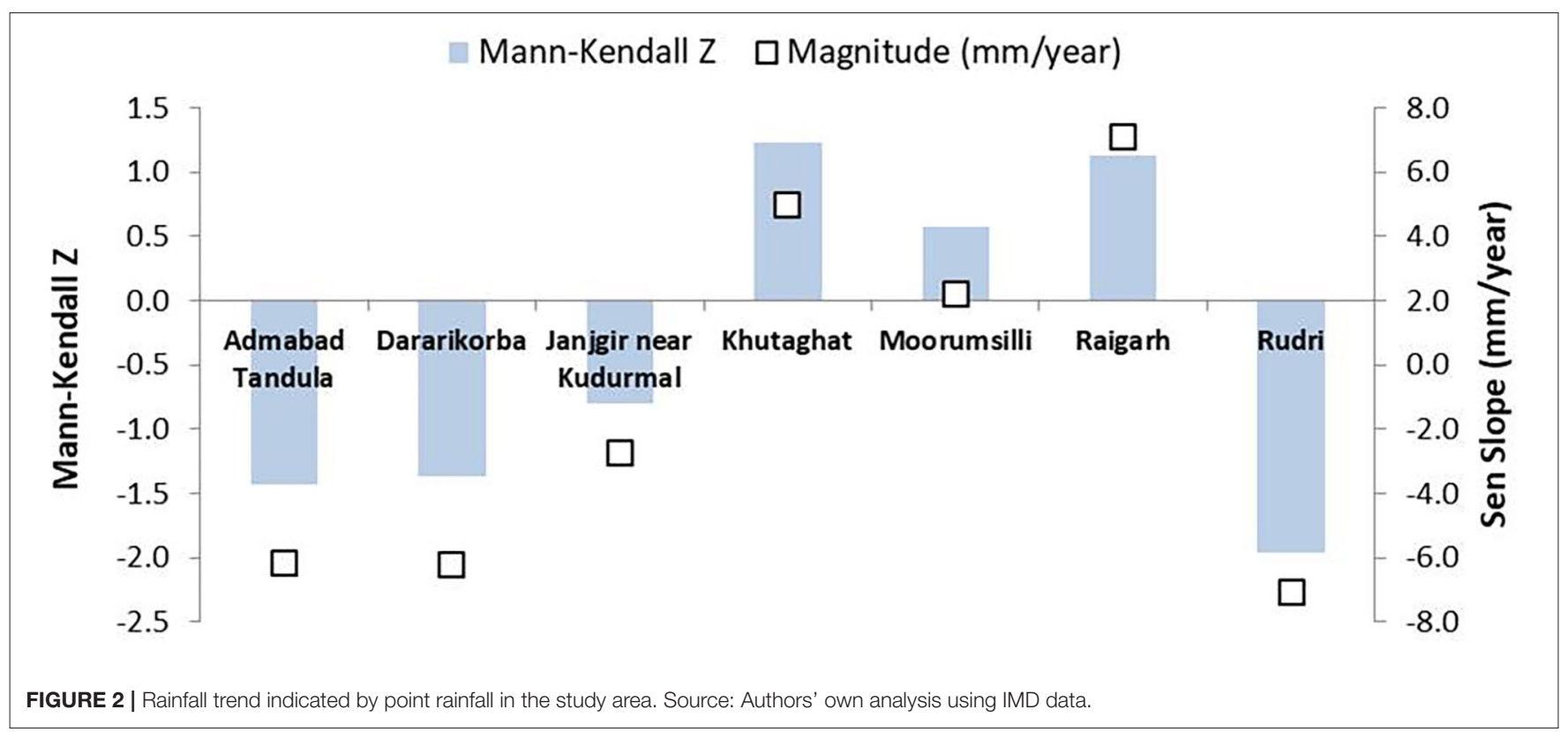

TABLE 2 | Analysis of rainy days of seven rain gauge stations in the study area.

\begin{tabular}{lcccc}
\hline Rain gauge stations & \multicolumn{4}{c}{ No. of rainy days } \\
\cline { 2 - 5 } & Mean & CV (\%) & Maximum & Minimum \\
\hline Admabad & 51 & 21 & 75 & 27 \\
Dararikorba & 80 & 17 & 102 & 36 \\
Janjgir & 61 & 19 & 91 & 40 \\
Khutaghat & 54 & 34 & 89 & 20 \\
Moorumsilli & 64 & 17 & 92 & 42 \\
Raigarh & 72 & 21 & 103 & 36 \\
Rudri & 61 & 19 & 95 & 39 \\
\hline
\end{tabular}

Source: Authors' own analysis using IMD data.

ranging from 0.44 (Dararikorba) to 0.50 (Admabad and Raigarh). For Janjgir which was the fourth location, it was 0.46 .

Further, the rainfall pattern showed a decreasing trend in six out of the seven locations (Figure 3). For only one location (Raigarh), the rainy days increased over a period of 41 years. However, a statistically significant long-term trend in the number of days of rainfall occurrence was found in three out of the six locations. They are Daraikorba, Admabad, and Khutaghat. The average decline in rainy days varied from 0.375 for Dararikorba to 1.0 in the Khutaghat. For the only location where the longterm trend in rainy days was positive, it was found to be statistically insignificant.

\section{Observed Streamflows in the Study Area}

The historical data of stream flows (1978-79 to 2010-11) recorded at the two important gauging sites in Mahanadi river basin by the CWC were used for the analysis. One of the gauging sites (Basantpur) is located immediately upstream $(\mathrm{u} / \mathrm{s})$ of Hirakud reservoir, the latter being the terminal site of the upper and middle sub-basins. The annual inflows at a gauging site in Basantpur and that at another gauging site (Kurubhata) in a tributary of Mahanadi which joins the trunk river downstream of Basantpur were added to get the estimated total streamflow $\mathrm{u} / \mathrm{s}$ of Hirakud reservoir. The maximum observed flow was 56,473 million cubic meters (MCM) during 1994-95 and the minimum was 8,643 MCM during 2000-01 (refer to Figure 4).

The analysis of annual stream flow data for "probability of exceedance" shows that in $75 \%$ of the years, the minimum annual flow $\mathrm{u} / \mathrm{s}$ of Hirakud dam would be around 15,730 MCM. This is not the runoff generated in the upper catchment area of the Hirakud, but the excess flow available after all the (effective) diversions through reservoirs and diversion structures for various consumptive uses.

\section{Groundwater Resources}

The aquifer system of the Mahanadi basin is complex and heterogeneous. They are largely consolidated formations consisting of sandstone, shale, limestone, basalt gneiss complex (BGC), granite, gneiss, and basalt. A very small fraction of the geographical area is under alluvium. In the upper and middle Mahanadi sub-basins, four major geological formations, viz., sandstone, shale, limestone, and BGC are found (CWC and NRSC, 2014). The groundwater recharge potential in consolidated formations is limited due to poor storage space in the aquifer.

Using the official estimates of CGWB, the total annual renewable groundwater in the area of the 15 districts (assessment units used for groundwater resource evaluation) falling in the upper and middle sub-basins of Mahanadi was estimated to be 6,540 MCM. This takes into account the effective recharge during the monsoon and non-monsoon periods and the natural discharge during the non-monsoon period. Against this, the estimated total annual abstraction is 3,146 MCM. Thus, the stage 


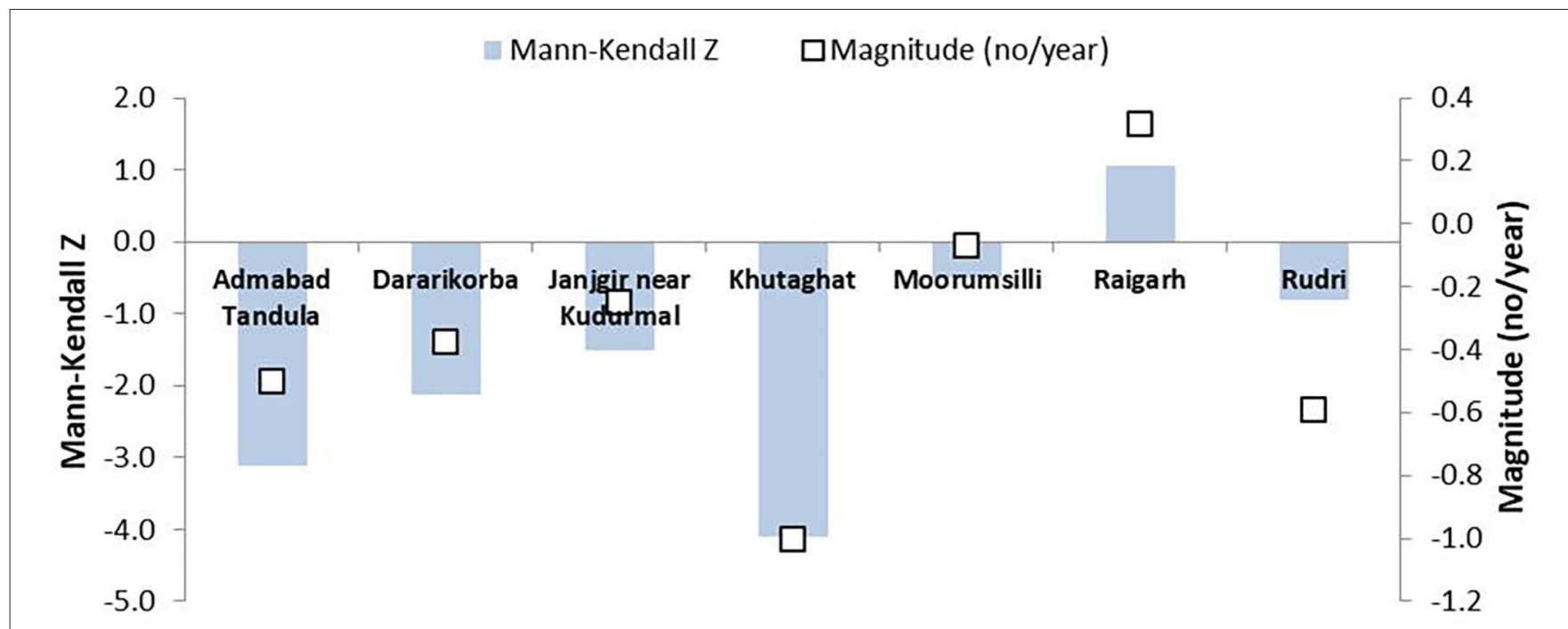

FIGURE 3 | Rainy days indicated by point rainfall in the study area. Source: Authors' own analysis using IMD data.

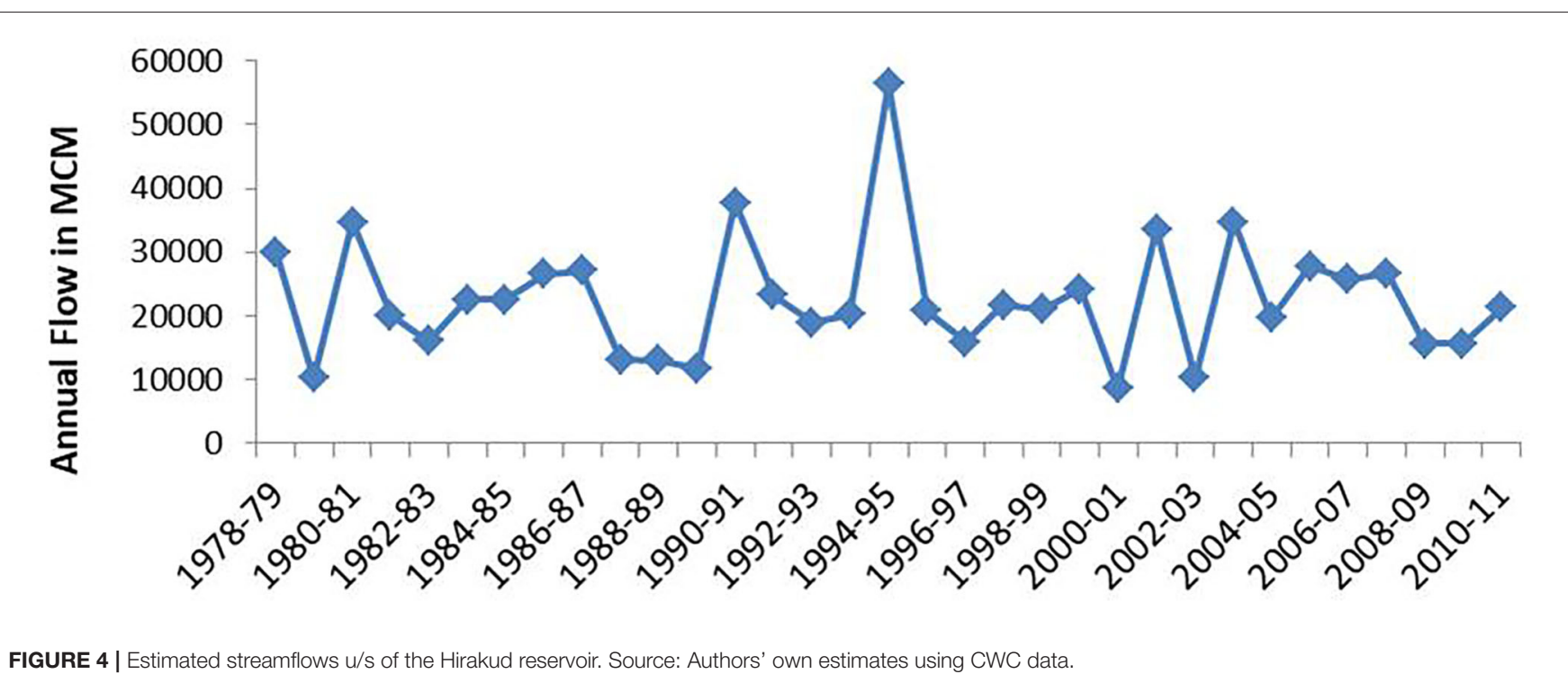

of groundwater development (abstraction/net recharge) in the study area at the aggregate level as per official data is quite low, i.e., $48 \%$. District wise analysis also shows that the stage of development is $<50 \%$ in 10 out of the 15 districts.

According to the estimates prepared using CGWB data, the natural discharge during the non-monsoon season (recorded as base flow) is only 475 MCM. However, the long term (197879 to 2010-11) mean annual lean season flow (represents the natural groundwater discharge provided there are no major rainfall events during that period) in the study area is $1663 \mathrm{MCM}$. These estimates are based on the observed flows at Basantpur and Kurubhata and after removal of hydrological years when substantial rainfall occurred during the non-monsoon months to represent the actual base flow alone. Thus, the figures of natural discharge considered by CGWB for arriving at the annual utilizable groundwater resources are under-estimates, and that the actual utilizable recharge is much less than what is available from their methodology. The difference is in the order of magnitude of 1,100-1,200 MCM.

\section{Rainfall-Runoff Models for Different Catchments}

The spatial variability in rainfall within the two sub-basins is not high. Thus, the average annual rainfall of upper and middle subbasins can be considered as representative of the rainfall in the two catchments which were identified for developing the rainfallrunoff model, for each sub-basin. The selected catchments are Andhiyarkore and Pathardi in the upper sub-basin, and 


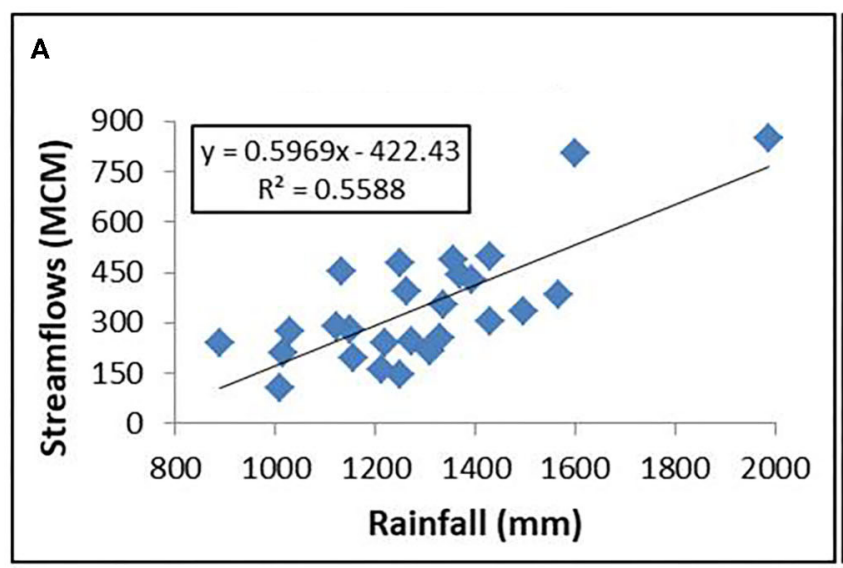

B
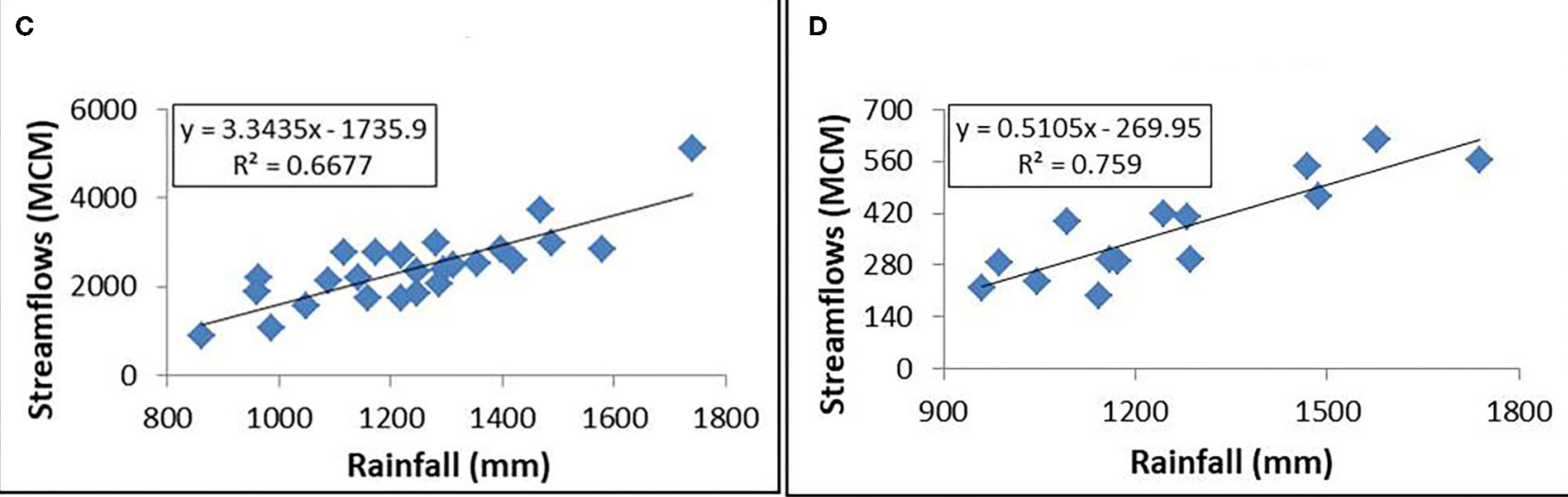

FIGURE 5 | (A-D) Rainfall-runoff relationships for the selected catchments in the Mahanadi basin. Source: Authors' own analysis.

TABLE 3 | Rainfall-runoff models for the four selected catchments.

\begin{tabular}{lccc}
\hline Catchment name & Catchment area (Sq. km) & Rainfall-runoff relationship & Rainfall-runoff model (mm/unit area) \\
\hline Andhiyarkore & 2210.0 & $Y=0.597 X-422.4$ & $Y=0.27 X-191.00$ \\
Parthardi & 2511.0 & $Y=1.517 X-1106.3$ & $Y=0.46 X-440.50$ \\
Kurubhata & 4625.0 & $Y=3.343 X-1735.9$ & $Y=0.722 X-375.10$ \\
Manendragarh & 1100.0 & $Y=0.5105 X-269.9$ & $Y=0.46 X-245.50$
\end{tabular}

Source: Authors' own estimates.

Kurubhata and Manendragarh in the middle sub-basin. Some data points, i.e., data pertaining to the hydrological year, 2003-04 for Andhiyarkore, 1991-92 for Pathardi, 1991-92 and 1999-2000 for Kurubhata, and 1996-97 and 1997-98 for Manendragarh, were treated as outliers and not considered for the analysis. The years 1991-92, 2000-01, and 2002-03 were drought years (won't represent the hydrological processes that occur in normal years), and 1990-91, 1994-95, 1997-98, and 2003-04 were wet years (data collection was not proper owing to flood situation).

For all the selected catchments, the regression relationship between the average runoff (dependent variable) and average rainfall (independent variable) is linear (refer to Figures 5A-D). The regression curve for Andhiyarkore can be chosen as the rainfall-runoff relationship for the upper sub-basin as it gives the best fit. Similarly, the model established for Manendragarh can be chosen for estimating future runoff for the middle subbasin. However, in both cases, the mathematical equations should be divided by the area of the catchment to obtain the runoff rate for a unit catchment, for a given rainfall "X." The rainfallrunoff models for the four catchments are given in Table 3. The rainfall-runoff regression equations in the last column of Table 3 would produce runoff $(\mathrm{Y})$ for the rainfall values $\mathrm{X}(\mathrm{mm})$ per sq. $\mathrm{km}$ area in $\mathrm{mm}$. These models can be used to estimate the total runoff from other catchments, having similar hydrological characteristics, in the respective sub-basins.

\section{Water Allocation and Use in the Study Area}

As data on stream flows in the basin suggest, water use (especially in agriculture) in the study area can change dramatically from a wet year to a dry year. In wet years, the actual use of water for 


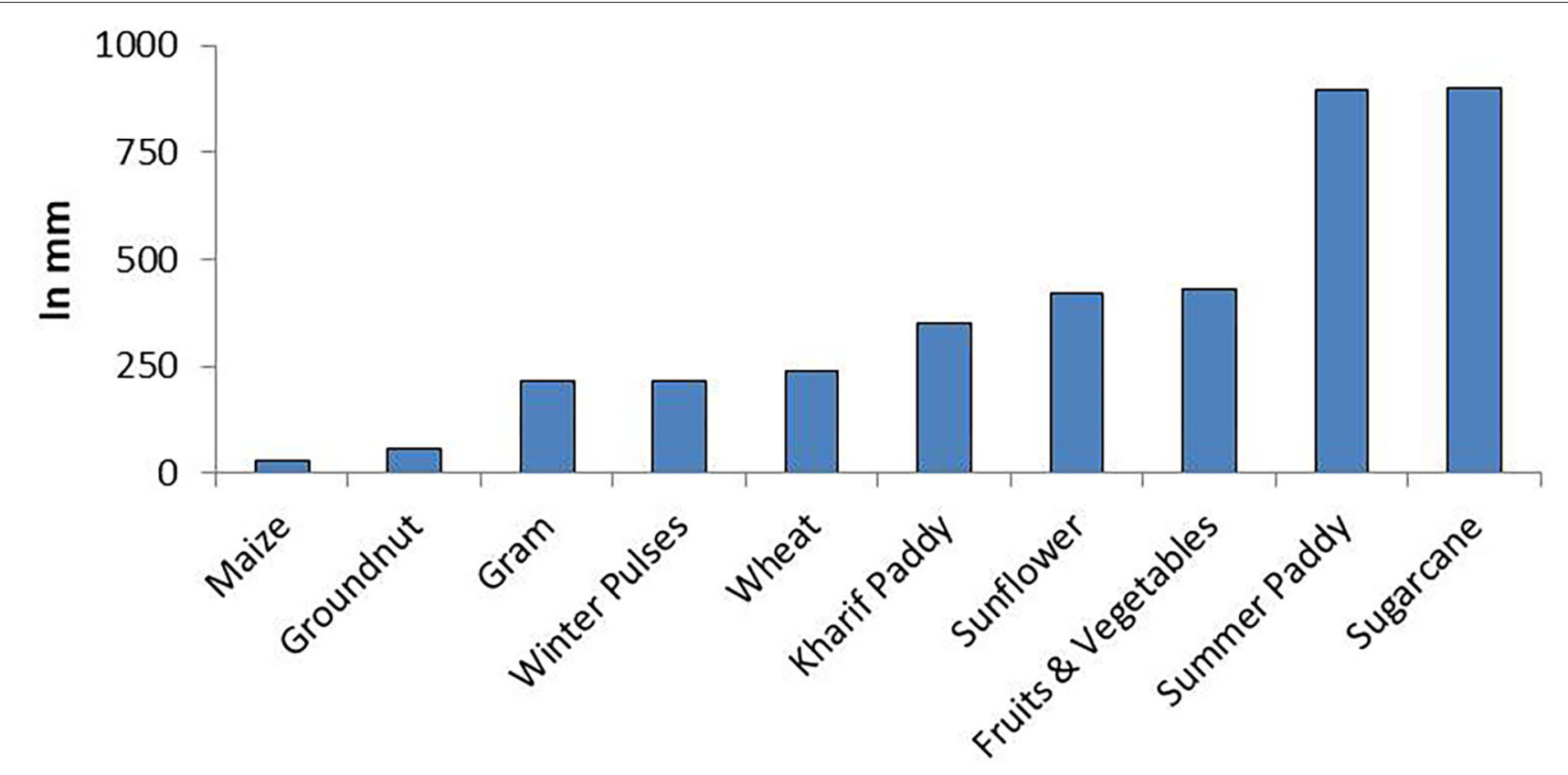

FIGURE 6 | Average irrigation water requirement for different crops in the study area. Source: Estimates based on FAO CROPWAT.

agriculture can increase due to increase in area under irrigation, especially during winter, though total water requirement per unit area would be less owing to higher soil moisture availability. In dry years, the overall shortage of water -due to limited amount of water released/diverted from reservoirs/weirs and limited water available in wells and local storage systems-would limit irrigation water use. Against this, the total water inflows (available from precipitation) available for meeting various consumptive needs could change dramatically, resulting from excessively high runoff and high groundwater recharge in a wet year to extremely low runoff and groundwater recharge in a dry year. Therefore, in a wet year, the storage change (groundwater storage change and river discharge) can be very positive and in a dry year, the overall storage change can come down to become very small, with a negative annual groundwater storage change. For this study, water use in various sectors (agriculture, domestic, livestock, and industries) was estimated for the normal rainfall year (2010-11 in this case).

The total irrigated area in the study part of the basin is 1.57 million hectares (m. ha) in 2010-11, which is 39\% of the gross cropped area. Around $63 \%$ of this irrigation is from surface sources (canals, tanks, and river lift), with 57\% from public canals alone. Paddy accounts for $84 \%$ of the gross irrigation. Other irrigated crops are pulses, fruits and vegetables, wheat, sugarcane, sunflower, groundnut, mustard, maize, and soyabean. Consumptive water use in irrigation is estimated to be 6,250 MCM for the year 2010-11. This analysis considered all the irrigated crops in different seasons, and the irrigation water requirement (for the weather parameters) using FAO CROPWAT (refer Figure 6).

About 19.3 million people reside in the study area, of which the urban population is about $26 \%$. A good portion of the water demand in urban areas is met from surface reservoirs and in rural area from groundwater sources. The total estimated water use (based on the supply norms mentioned in section Estimating Current Water Use) in rural domestic sector is $275 \mathrm{MCM}$ per annum for 14.2 million people, and that in the urban domestic sector is $83 \mathrm{MCM}$ for about 5 million people. For the latter, the assumption is that $70 \%$ of the water supplied for urban uses (at the demand site) is available as return flows (to river) through the sewerage system, and only $30 \%$ is depleted (actually consumed by the urban population). For rural areas, it was assumed that all the supplied water was consumed.

There are a total of 9.4 million livestock, comprising cattle, buffaloes, goats, sheep, and donkeys in the study area. The water demand for the livestock was estimated using the methodology by Pallas (1986) that considers the different types of livestock, the average number of livestock units each type of livestock constitute, water requirement per total livestock unit (TLU) for each type of livestock, and the climate of the area (hot and subhumid). Further, it was assumed $100 \%$ of the supplied water is consumed by the livestock. Following this approach, the water use in the livestock sector is estimated to be $90 \mathrm{MCM}$ per annum.

The industry is a major claimant for the water from the basin. The available official data shows that there are a total of 125 industries in the upper and middle sub-basins, which are allocated surface water by the Water Resources Department. These industries include thermal power stations, power and steel plants, iron and steel plants, mineral industries, and breweries. Of these, 96 are thermal power plants and power and steel plants and having a capacity to generate 59,224 mega-watts (MW) of power. The total amount of water allocated annually to all these units put together (as per official estimates) is 2,172 MCM of water per annum. The amount of water required by the thermal 


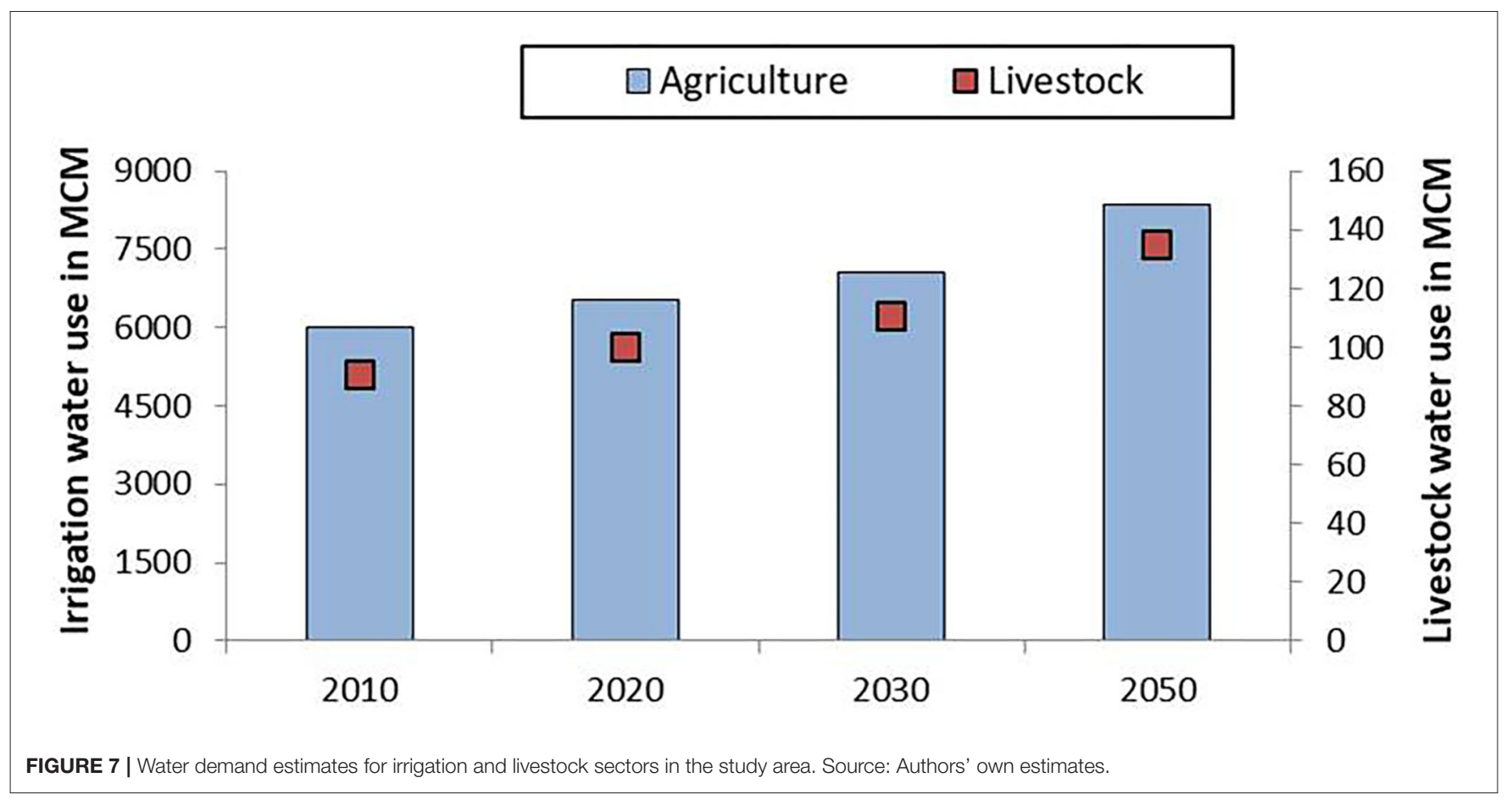

power units and steel and power units was estimated to be 2,162 MCM of water, based on a norm of 100 cubic meter (cu m) of water per MW-day of electricity generated in coal-based thermal power plants (Bhattacharyya, 1997). However, the total volume of water allocated for power generating units is only 1,940 MCM. The slightly lower water allocation against the requirement for the thermal power plants could be due to the reason that some of the plants are not running in their full capacity. It can be safely assumed that $80 \%$ of this water to be consumed by the plants for various processes (boilers, evaporative cooling, other plant operations, and domestic use by the townships), and nearly $20 \%$ is available as return flows to the rivers/streams. It is also assumed that all the water allocated to other industries is consumed and there is no return flow. Hence, we estimate the consumptive water use for industries to be about 1,784 MCM per annum.

Thus a total of $8,482 \mathrm{MCM}$ of water was consumed in a normal rainfall year. Out of this, $74 \%$ was consumed in agriculture, $21 \%$ in industrial, $4 \%$ in domestic, and only $1 \%$ in the livestock sector.

\section{Future Water Demand Under Business as Usual Scenario} Irrigation and Livestock Water Demand

The estimation of future irrigation water demand considered past growth trends in irrigated area and the total land area available for area expansion. While the past trends in irrigated area would indicate the pace at which the area has to grow to meet the future agricultural production requirements, the land area would act as a constraint. In the case of livestock sector, the past growth trends in the population of different types of livestock were considered for estimating future livestock water demand.

Between 2010-11 and 2014-15, the irrigated area had increased at a CAGR of 3\%. Between 2007 and 2012, the overall livestock had recorded a CAGR of $1 \%$. Considering the respective growth rates and water supply estimates for 2010-11, the water demand in the irrigation and livestock sectors up to 2050 was estimated to be 8,343 and $135 \mathrm{MCM}$, respectively. In a short term (by 2030), it will be 7,075 and 111 MCM, respectively (refer to Figure 7).

\section{Domestic Water Demand}

The population is an important driver of water demand in many sectors, especially domestic sector and agriculture. Also, the way population drives water demand depends on where the population growth takes place. Urban population growth will have a much higher demand for water as compared to that of rural population, for the same level of growth. Analysis of data on population of urban and rural areas in the study area for the period from 1971 to 2011 shows that the urban growth rate was very high during the first two decades (1971-81 and 19811991) and came down and stabilized at CAGR of 3.3\% during the last decade (2001-11). However, the rural population growth rate had been fluctuating between a lowest of $1.23 \%$ per annum and $2.08 \%$ per annum. For future projections, an annual growth rate of $3.3 \%$ was considered for urban areas and $1.59 \%$ for rural areas. The growth rate considered for rural areas is the average of the decadal growth rate for four consecutive decades prior to 2011.

Under the business as usual scenario (past trends to continue), by 2050 , the urban and rural population would reach 18 and 26.3 million, respectively. Considering a water supply norm of 


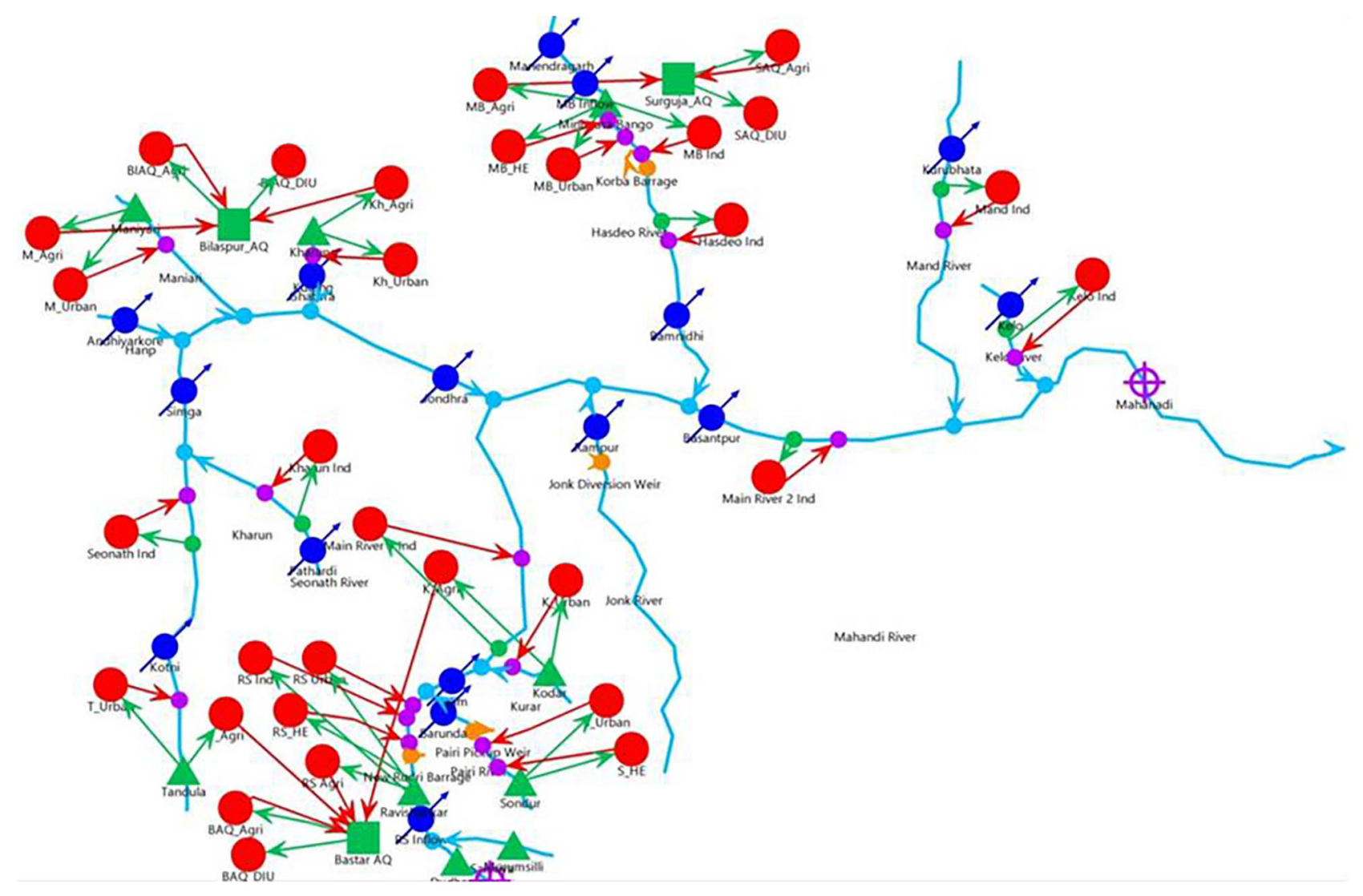

FIGURE 8 | The WEAP configuration for the study area.

150 lpcd for the urban areas and $55 \mathrm{lpcd}$ for the rural areas, the urban domestic water demand and rural domestic water demand are estimated to reach $899 \mathrm{MCM}$ per annum and $631 \mathrm{MCM}$ per annum, respectively, for the year 2050. The corresponding figures for 2030 were 498 and 425 MCM, respectively.

\section{Industrial Water Demand}

Thermal power is the most important industrial sector, which demands water from the basin, accounting for nearly $90 \%$ of the total industrial water demand. Between 2011 and 2016, the installed thermal power generation capacity has recorded a CAGR of $5.1 \%$. During the same period, the other major type of industry in the study area, i.e., iron and steel, had recorded a CAGR of $4.4 \%$. Considering the CAGR and water allocation for different industries in 2010-11, the industrial water demand is expected to grow to $4694 \mathrm{MCM}$ by 2050 . It would be $3159 \mathrm{MCM}$ in 2030 .

\section{Future Water Balance Scenario for the Study Area \\ Setting and Configuration of WEAP Model}

To analyse the future water balance scenario for the study area in the Mahanadi basin, the WEAP model was used. The model has three components: [1] a supply programme to simulate various sources of water supply with respect to space and time; [2] a demand programme to simulate various demand sites in quantitative and qualitative with respect to space and time; and, [3] a network programme, which handles the conveyance systems for taking water from the supply sources to various demand sites and also the return flows (domestic and industrial wastewater, irrigation return flows, etc.) from demand sites to various sinks and sources.

The configuration of the WEAP is presented in Figure 8. In the configured WEAP model, one main trunk river and 12 tributaries (light blue lines), 3 groundwater supply nodes (green rectangles), 16 streamflow gauges (dark blue circles with arrow), 10 reservoir nodes (green triangles), 31 demand sites (red circles), 26 transmission links (red arrow), and 17 demand site return links (green arrow) were defined.

The configuration of WEAP was set up for the period beginning June 2009 and ending May 2050. The year 2010 (June 2009-May 2010) was taken as the base year and period 2011-2050 was considered for generating scenarios (also called reference years). The observed monthly river discharge (2 timesteps per month or 24 time-steps per year) for the period 1989-2011 were used as streamflow data for the 16 gauging stations defined on the Mahanadi river main stem and its nine tributaries. The observed flow data were allowed to repeat in the 
TABLE 4 | Future water balance scenarios modeled using WEAP.

\begin{tabular}{|c|c|c|}
\hline $\begin{array}{l}\text { Scenario } \\
\text { no. }\end{array}$ & Scenario & Description \\
\hline 1 & Base Case & $\begin{array}{l}\text { - It is the business-as-usual scenario where human population, livestock population, irrigated area, and industries continue to grow as } \\
\text { per the past trend (as discussed in section Future Water Demand under Business as Usual Scenario). } \\
\text {. The rainfall-runoff relationships, established on the basis of data of rainfall and runoff (refer to Table 3), were assumed to remain } \\
\text { unchanged for the catchments. }\end{array}$ \\
\hline 2 & High Growth & $\begin{array}{l}\text { - This scenario uses drivers that induce higher growth in demand for water for various consumptive uses in the basin. } \\
\text { - It is assumed that human population, livestock population, irrigated area, and industrial production will grow at a higher rate than } \\
\text { under the business-as-usual scenario. For all the sectors, an increase of } 50 \text { basis points }(0.5 \%) \text { over the past trend was considered. } \\
\text {. The rainfall-runoff relationships were considered to be unchanged as for the base case scenario. }\end{array}$ \\
\hline 3 & $\begin{array}{l}\text { End Use } \\
\text { Conservation in } \\
\text { Agriculture }\end{array}$ & $\begin{array}{l}\text { - This scenario uses certain drivers to affect reduction in demand for water through improvements in efficiency of use of water. } \\
\text { - It is assumed that water use efficiency in irrigation will be improved through the adoption of efficient irrigation technologies for certain } \\
\text { crops (only). The reduction in irrigation consumptive use of water was considered to be } 10 \% \text { in surface irrigated areas and } 5 \% \text { in } \\
\text { groundwater irrigated areas. } \\
\text {. Human population, livestock population, irrigated area, and industrial production continue to grow at the same rate as in the case of } \\
\text { the "base case." } \\
\text {. Further, the rainfall-runoff relationships for the catchments will remain unchanged as considered for the base case scenario. }\end{array}$ \\
\hline 5 & $\begin{array}{l}\text { Projected Future } \\
\text { Climate Change: } \\
\text { IITM Findings }\end{array}$ & $\begin{array}{l}\text { - This scenario uses the studies carried out by IITM, Pune using climate model, which shows that the rainfall in Mahanadi river basin } \\
\text { is expected to increase in the range of 5-20\% by the year } 2050 \text {. } \\
\text { - Since the earlier scenario (based on past trends in rainfall) shows low rainfall change, we have considered the upper value of } 20 \% \\
\text { change in rainfall over a period of } 40 \text { years as this represents the upper limit of change that is expected to happen in the basin. } \\
\text { - Two different socioeconomic scenarios were incorporated into the model, both characterized by regionally focused development } \\
\text { but with priority to economic issues in one (referred to as A2) and to environmental issues in the other (referred to as B2). }\end{array}$ \\
\hline 6 & Drought Scenario & $\begin{array}{l}\text { - It captures the situation during the drought years, determined on the basis of a significant reduction in annual stream-flows from the } \\
\text { mean values in the basin. } \\
\text { - The years chosen for analyzing the drought year water balance are } 2022-23,2024-25,2044-45 \text {, and } 2046-47 \text {. } \\
\text { - All parameters influencing the demand for water in various sectors of the basin were kept same as the base case scenario. }\end{array}$ \\
\hline
\end{tabular}

WEAP model as the simulated river flows for the future base case scenario.

For the reservoir nodes, measured monthly flows were considered as the "head flows" into the reservoirs. The elevationarea-storage data was also used for all the reservoir nodes for the model to work out the releases. For the aquifers, data on storage capacity, annual natural recharge, and withdrawal was provided.

Each demand sites comprises a demand tree consisting of sectors viz., agriculture, domestic, livestock, and industries, subsectors (for instance different crops, livestock types, urban and rural domestic water user, etc.), annual activity level, annual water use rates at the branch and sub-branch. The model will estimate the water supply requirement for each demand site taking into account the values of "conveyance losses" as stipulated in the model for different types of transmission links (whether canals or pipelines or river channels). The conveyance losses were considered to be 5-20\% for agriculture and 5\% each for domestic, livestock, and industrial demand sites.

A total of six water balance scenarios were modeled with regard to socio-economic changes and climate change, including a base case wherein the past trends with regard to socio-economic changes would continue and there will be no change in the climate. The details on the modeled scenarios are presented in Table 4.

\section{Results From the WEAP Model}

The water balance results for all the scenarios (except Scenario 6 which is discussed in the next section) generated by the WEAP model are presented in Figure 9. Even under the base case scenario (Scenario 1), there would be a some gap between water demand for various consumptive uses and water supplies from the existing systems by the year 2050 (the difference between supply requirement and actual supplies). The gap is estimated to be $1,801 \mathrm{MCM}$ in 2030 and 2,812 MCM in 2050. But there will still be a large amount of outflow from the upper and middle sub-basins (study area) of the Mahanadi in 2050 (about 26,545 MCM). The water shortage will mainly affect irrigation of winter crops, as per the "water allocation priority" defined in the model. As a result, farmers in command areas and well irrigators will end up under-irrigating the winter crops.

Under a high growth scenario (Scenario 2), the water deficit is expected to increase to 5,005 MCM by 2050 (refer to Figure 9). The water balance estimates show that the demand-supply gap is lower in 2020 as compared to 2010 in all scenarios. This might 


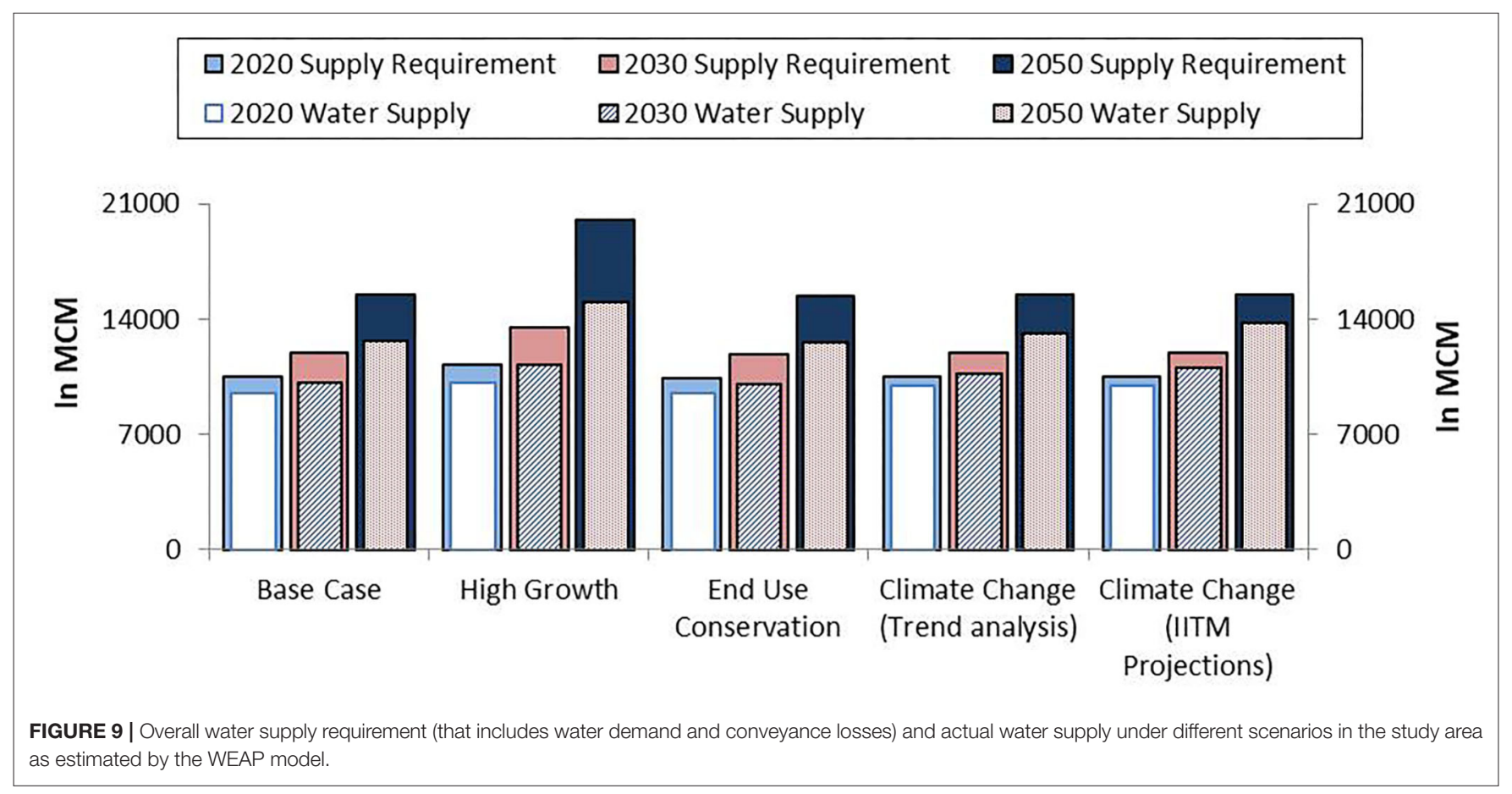

appear unrealistic given the fact that the demand only increases with time under any scenario. Such a situation emerges merely because there is high inter-annual variability in water supplies from surface sources and it is just a coincidence that the annual flows in the river and its tributaries in 2020 are much higher than that of 2010, and because of lack of multi-annual storage, this would affect the demand-supply gap from year to year. However, what is important is that the overall gap between demand and supplies is only likely to increase with time as per the first three scenarios if we consider the general trends in demand for water in the basin. Under the high growth scenario, the annual outflow is estimated to be 25,286 MCM in 2050.

The demand management interventions in agriculture (Scenario 3) will be able to reduce the demand for water in the basin to some extent, while it also reduces the supplies slightly. Such a phenomenon occurs due to a reduction in return flows occurring as a result of efficiency improvement in irrigation which ultimately affects the groundwater yield. The demandsupply gap under this scenario in 2050 will be around 2,773 MCM, and the reduction in deficit (demand-supply gap) as compared to the business-as-usual scenario is only 39 MCM.

Under a scenario of climate change (Scenario 4), there would be some improvement in water supplies as compared to the base case scenario (by around 440 MCM in 2050) owing to an increase in the catchment yields resulting from higher rainfall. This improvement occurs even without any change in water production and supply infrastructure. Yet, it will not be sufficient to cover the expected gap between demand and supplies. The gap will be 2,373 MCM. The outflows during 2050 will be 26,771 MCM.
Under the second climate change scenario (IITM-Climate model) (Scenario 5), the rainfall is expected to increase by a maximum of $20 \%$ over a 40 year period. Under this scenario, as expected, the water supply potential even with the existing infrastructure increases to $13,782 \mathrm{MCM}$, and the supply requirement would be $15,466 \mathrm{MCM}$ by the year 2050 . Hence the gap in demand (supply requirement) and supplies would be 1,684 MCM. The amount of streamflow available (as the outflow from the study part of the basin) just upstream of the Hirakud reservoir would be 28,697 MCM in the year 2050, highest among all the scenarios.

\section{The Drought Scenario}

Based on the projection of past and existing stream flows to future by the WEAP model, 2022-23, 2024-25, 2044-45, and 2046-47 are expected to be drought years in the study area of the Mahanadi river basin. Hence, the basin does not experience frequent droughts. With each drought event, the gap between required water supply and actual water supplied will accentuate further as necessary infrastructure for water storage and conveyance is inadequate. This gap is expected to be about 2,251 MCM in 2046-47, almost twice that of 2022-23 (refer to Figure 10). Also, during a drought year, the outflows from Chhattisgarh part of the basin will reduce substantially. During the expected drought of 2046-47, it will reduce by around $50 \%$ in comparison to long term (2010-2050) average annual outflows from the study area of the basin under a business-as-usual scenario. Nonetheless, there will be outflows even during the drought years (refer to Figure 10). 


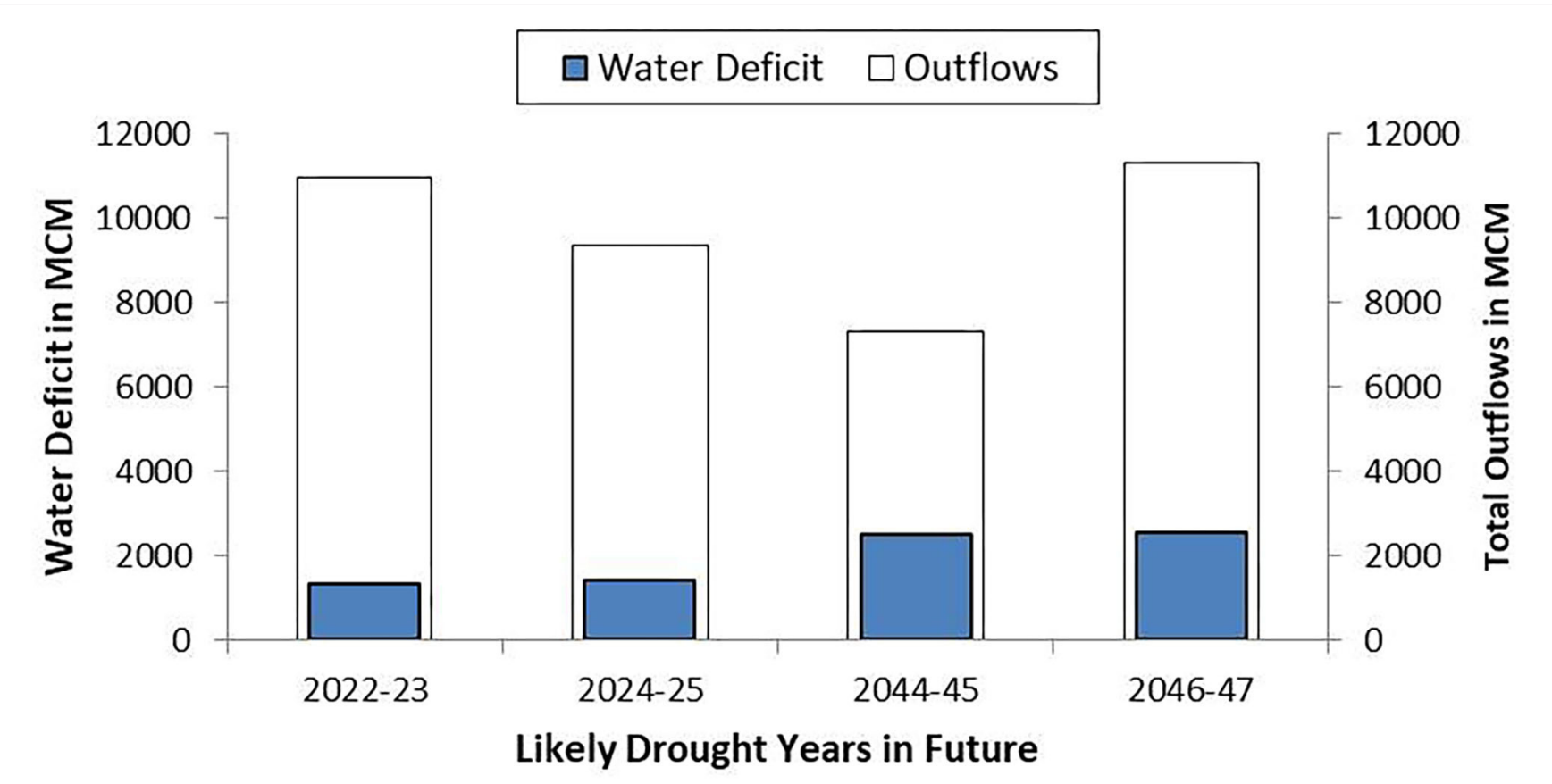

FIGURE 10 | Water balance during drought years in the study area as estimated by the WEAP model.

\section{DISCUSSION}

The WEAP results show that there will be sufficient water flowing out of the study area even in 2050 that can be harnessed for increasing the water supplies for meeting various needs, without compromising the needs of the lower riparian state. For the entire basin, the estimated annual outflow (at $75 \%$ dependability) is about $29,000 \mathrm{MCM}$. This is the volume of water that goes unutilised and drains into the sea (Bay of Bengal) as estimated using the streamflow data collected by the Central Water Commission for the terminal gauging point in the basin. However, the impact of additional water storage on downstream flows will be high during drought years. Nevertheless, it is evident that to reduce the demand-supply gap, there is a need for augmenting the supplies through more water storage/diversion infrastructure.

\section{Addressing Future Water Demands Given Climate Change: Scope for Creating Multi-Annual Water Storages}

Addressing future water problems under a scenario of climate change in the Mahanadi basin, as predicted by models, appears to be far less challenging than that under a "business as usual scenario." The reason is that the major water problem of the upper and middle sub-basins is water scarcity and intersectoral competition for water especially between agriculture and industries, industries and domestic water supply, and agriculture and domestic water supply, which worsens during droughts.
Under the climate change scenario, the basin is expected to yield much more water than at present, but the inter-annual variability in stream-flows will be more. During the wet years in the future, there will be more runoff as compared to such years in the past. The problem will be during drought years as runoff from the catchments falls sharply. While the agricultural system will automatically get adjusted to suit the available water in the reservoirs, rivers, and aquifers (mainly through a reduction in winter cropping and deficit irrigation of the crops), it will be difficult to manage water supplies for thermal power plants which consume large amounts of water, and water supplies for livestock, and rural and urban domestic sectors.

Hence, the challenge will be of building more storage infrastructure not only for providing multi-annual storage of runoff that occurs during wet years for use during years of droughts, but also for ensuring additional supplies of water for meeting the growing demand for water from different sectors in normal years. In addition to increasing the multi-annual storage capacity in large reservoirs, the local tanks and ponds need to be rejuvenated so that they provide some cushioning. However, rejuvenation doesn't imply that its capacity is to be enhanced. It is about protecting their catchments, by preventing land encroachment for crop cultivation.

The buffer storage of water from the large reservoirs can be released for high priority uses such as rural domestic and municipal uses during droughts, when the wells dry up. Also, it will be advisable to release some water from the large storages downstream into the rivers and tributaries as it will help protect the in-stream uses of water (fisheries, bathing, and washing) and subsistence farming based on river lifting. 
As regards groundwater, the hard rock aquifers of the region do not provide much space for buffer storage of the additional infiltration that occurs during wet years, and appears as base flow during the monsoon season itself, contributing to the runoff from the catchments. However, the situation slightly improves, if a wet year was followed by a drought year. Nevertheless, the aquifer systems as such do not have stocks (static groundwater) that would be available as a buffer for use in drought years, when the recharge reduces. Hence, groundwater in the region cannot provide drought resilience (Kumar et al., 2021). Therefore, it is all the more important that more surface water storages with multiannual storage facilities are developed in the region to provide climate resilience.

\section{Coping With Extreme Events: Rationing Water Allocation}

In the study area, the amount of land under cultivation during the winter season is much smaller in comparison to that during the autumn season. Therefore, it is quite likely that with water saving per unit area, the farmers expand the area under the crop as a result of adoption of water-saving irrigation technologies and practices. Hence, water allocation to irrigation will have to be rationed in volumetric terms to create an incentive for efficient use of the supplied water and to achieve an actual reduction in water demand (Kumar and van Dam, 2013). This would require institutional mechanisms such as water entitlements or water use rights in irrigation commands, to restrict water use at the aggregate level. Water entitlements and water rights need to be defined and enforced by legitimate agencies (such as Water Resources Department) for individual users or groups of users (Rosegrant and Binswanger, 1994; Rosegrant and Gazmuri, 1994; Kumar, 2006, 2010).

In the case of groundwater, "water rights" will have to be defined in volumetric terms for individual users, with its delineation from land rights (Kumar, 2005; Bassi, 2014). In the case of canal commands, water entitlements can be designed for farmer organizations (WUAs under minors or distributaries). These rights and entitlements can change from year to year and from seasons to seasons depending on the amount of water stored in the reservoir and or amount of water available in the streams for diversion in different seasons. Nonetheless, the volumetric allocation of rights for individual users and groups of users would be high during wet years, and there could be sharp cuts in allocation to farmers during dry years. However, different models are possible. One of them is that the water resources department can fix a minimum volumetric entitlement (per ha of land) for all years, and allocate additional water every year depending on the amount of flows.

These water entitlements or rights need to be made tradable to encourage efficient use in the given sector or transfer of water to the alternative use of higher value (Rosegrant and Binswanger, 1994; Rosegrant and Gazmuri, 1994; Bassi, 2014). One should anticipate farmers reallocating water for agricultural uses that generate high economic value than paddy or trading water to industries at a remunerative price during drought years.
Volumetric water pricing will have to be introduced to ensure that all the users are confronted with the opportunity cost of using water at all times and the agency which allocates water recovers the resource fee and cost of its provisioning (Shen and $\mathrm{Wu}, 2017)$. Or else, it is quite likely that whenever there is overallocation, people resort to inefficient uses as they would not incur high cost of using it. However, the unit prices will have to vary across sectors depending on the ability to pay. Since water use efficiency is generally much higher in industrial use as compared to irrigation, the latter being a low value use, the industrial sector will be able to pay a much higher price for water as compared to farmers. Further, the volumetric price of water can keep varying depending on the annual water availability. During drought years, the prices will have to be higher than that in wet years and normal years as the average economic value of water use and social and environmental value of water would be much higher owing to overall scarcity of water and the higher price that the users would be willing to pay. However, in the case of groundwater, the price should include only the resource fee, as the cost of production and supply of water is borne by the well owners.

There are empirical studies that analyzed the impact of volumetric water rationing and water pricing in India. They showed that a higher price for water can lead to a reduction in irrigation demand, with no adverse effect on the economic viability of farming. A comparative study of shareholders of tube wells in north Gujarat and individual well owners (the latter are not confronted with the opportunity cost of using water) showed that the shareholders of tube wells whose water entitlements are fixed on volumetric terms, and who pay for water on an hourly basis, the overall irrigation water productivity in crop production was much higher than that of well owners (Kumar, 2005). A subsequent study in eastern Uttar Pradesh, South Bihar, and north Gujarat of four different categories of farmers (well owners having electric pump, well owners having diesel pump, and water buyers from the electric and diesel pump operated private wells) showed that the farmers who are confronted with positive marginal cost of using water (water buyers of electric and diesel pumps and diesel well owners) secured not only higher water productivity in physical and economic terms, but also higher net income return per unit of land than those who were confronted with zero marginal cost of using water and electricity (electric well owners). The former used all inputs, including water efficiently, and modified their cropping system with a higher proportion of the land allocated to more water efficient vegetable crops. Further, higher cost of irrigation (as in the case of buyers of water from diesel well commands) did not result in reduction in net income (Kumar et al., 2011, 2013).

\section{Improving Water Use Efficiency in Thermal Power Production}

The industrial water consumption is very high in the study area. Among the various industries, thermal power production and steel and power consume the largest amount of water. Many of the power plants are quite old and use processes that are not so water efficient. A saving to the tune of $1.0 \mathrm{cu} \mathrm{m}$ of water per 
mega-watt hour (MWh) of electricity produced from coal based thermal power plants can be achieved by the year 2030 and 2050, if the water intensity of power generation is reduced from the existing 3.5-2.5 cu m per MWh of electricity produced. This can lead to a total saving of around $525 \mathrm{MCM}$ of water per annum, if all the installed capacity (59,000 MW) gets operational. One way to encourage thermal power stations to aggressively pursue water use efficiency plans is to raise volumetric water charges to such a level that the cost of revamping the plants to reduce water use by one unit is less than the marginal cost of using a unit volume of water.

\section{CONCLUSION}

Mahanadi river basin is characterized by high inter-annual variability in rainfall and stream-flows. Analysis of long term trends in rainfall of seven locations in the basin shows an increase in rainfall in four locations and a decrease in rainfall in some others. As per the trend analysis of historical data, the average annual rainfall change is expected to be in the range of -6.2 to $7.1 \mathrm{~mm}$. The rainfall-runoff modeling carried out for four typical catchments in the upper and middle Mahanadi basin based on estimated values of spatial average rainfall for the respective catchments and observed stream-flows shows a linear relationship. Using the rainfall trend analysis and the developed rainfall-runoff model, the change in average annual runoff is estimated to be in the range of -0.00004 to $0.0001 \mathrm{cu} \mathrm{m} / \mathrm{s} / \mathrm{sq}$. $\mathrm{km}$ in future in different catchments.

The minimum annual flow $\mathrm{u} / \mathrm{s}$ of Hirakud dam at $75 \%$ dependability was estimated to be around 15,730 MCM. As per official estimates, the annual renewable groundwater resource in the study area is 6,540 MCM. However, as per our estimates, the net groundwater availability is less than this by about 1,100 MCM as there are substantial base flows during the non-monsoon months there were under-estimated by the official agency, i.e., CGWB. As per our assessment for 2010-11, the amount of water beneficially utilized in various sectors is only 8,482 MCM. This includes irrigation water use, industrial water use, urban and rural domestic water use and voluntary livestock water consumption. The industry is the second largest consumer of water in the basin, accounting for $17 \%$ of the total consumptive water use.

In future, with a wide range of socio-economic changes, the Mahanadi river basin is expected to experience water shortages, resulting from the demand for water from competitive use sectors exceeding the utilizable water supplies from existing water infrastructure. As per the simulation study carried out using WEAP, if the current pattern of growth continues, the gap between water supply requirement and the supplies will be around 1,801 MCM in 2030 and 2,812 MCM in 2050. The demand-supply gap will be higher (5005 MCM in 2050) under a high growth scenario. Yet there will be sufficient water flowing out of the study area entering into Hirakud reservoir in normal and wet years to meet the downstream commitments. However, the deficit in water supply is expected to reduce under the scenarios of climate change, with more rainfall and stream flows.
It is proposed that the deficits of water in different sectors can be met by building more storage infrastructure that would increase the water supply potential, as there is a sufficient amount of water in the Mahanadi River flowing out of the upper and middle sub-basins in normal and wet years. Some scope also exists for reducing the demand for water in consumptive use sectors such as agriculture and industry. Drought years will however pose challenges as the total runoff from the upper catchment areas decline sharply. As only a small amount of water from the upper catchment will be flowing into the Hirakud reservoir during drought years, there will be immense competition for the available water between agriculture and industries.

The scope for water demand management in agriculture through water use efficiency improvements in crop production as a way to reduce the demand-supply gap, as predicted by the WEAP is not very large, given the unique cropping pattern of the region, dominated by irrigated paddy. Even if watersaving irrigation technologies are introduced in the irrigation commands in future, their use is unlikely to result in an aggregate reduction in water use in agriculture. There are some opportunities for reducing water use in the industrial sector by improving water use efficiency improvements in the order of around $525 \mathrm{MCM}$ per annum.

Thus, the most appropriate technical intervention for improving the climate resilience of the basin communities with regard to droughts and floods is to build storage infrastructure for multi-annual storage of runoff, thereby storing water during the wet year as a drought buffer. The volumetric storage capacity of such reservoir systems will have to be large enough to augment the flows into the Hirakud reservoir during drought years after meeting the overall water deficit from different sectors in such years. Further, volumetric rationing of water supplies in command areas can be resorted to by the Water Resources Department during drought years to affect a reduction in irrigation water demand.

\section{DATA AVAILABILITY STATEMENT}

The original contributions presented in the study are included in the article/supplementary material, further inquiries can be directed to the corresponding author.

\section{AUTHOR CONTRIBUTIONS}

MDK conceptualized the study and developed the methodological framework for assessing the impact of climate variability and change on water resources in the Mahanadi River basin. NB configured the WEAP for the upper and middle sub-basins of Mahanadi and modeled different scenarios of future water balance. Further, all the authors contributed equally to analysis of the data and WEAP model outputs, and writing the research paper. 


\section{ACKNOWLEDGMENTS}

The article is based on a report prepared by MDK and NB for Act on Climate Today (ACT) titled Water resource

\section{REFERENCES}

Allen, R. G., Willardson, L. S., and Frederiksen, H. (1997). "Water use definitions and their use for assessing the impacts of water conservation," in Sustainable Irrigation in Areas of Water Scarcity and Drought, eds J. M. de Jager, L. P. Vermes, and R. Rageb (Oxford: ICID), 72-82.

Bassi, N. (2014). Assessing potential of water rights and energy pricing in making groundwater use for irrigation sustainable in India. Water Policy 16, 442-453. doi: $10.2166 /$ wp. 2013.123

Bassi, N., Schmidt, G., and De Stefano, L. (2020). Water accounting for water management at the river basin scale in India: approaches and gaps. Water Policy 22, 768-788. doi: 10.2166/wp.2020.080

Batisani, N., and Yarnal, B. (2010). Rainfall variability and trends in semi-arid Botswana: implications for climate change adaptation policy. Appl. Geogr. 30, 483-489. doi: 10.1016/j.apgeog.2009.10.007

Bhattacharyya, S. C. (1997). An estimation of environmental costs of coalbased thermal power generation in India. Int. J. Energy Res. 21, 289-298. doi: 10.1002/(SICI)1099-114X(199703)21:3<289::AID-ER263>3.0.CO;2-N

CPHEEO (1999). Manual on water supply and treatment (Third edition-revised and updated). Central Public Health and Environmental Engineering Organisation (CPHEEO), Ministry of Urban development, Government of India, New Delhi.

CWC and NRSC (2014). Mahanadi basin: Version 2.0. Central Water Commission (CWC), Ministry of Water Resources, New Delhi and National Remote Sensing Centre (NRSC), Department of Space, Hyderabad, India.

Davis, K. F., Chhatre, A., Rao, N. D., Singh, D., and DeFries, R. (2019). Sensitivity of grain yields to historical climate variability in India. Environ. Res. Lett. 14:064013. doi: 10.1088/1748-9326/ab22db

Estrela, T., Pérez-Martin, M. A., and Vargas, E. (2012). Impacts of climate change on water resources in Spain. Hydrol. Sci. J. 57, 1154-1167. doi: 10.1080/02626667.2012.702213

GOI (1999). Report of the national commission on integrated water resources development plan. Ministry of Water Resources, Government of India (GoI), New Delhi.

Gosain, A. K., Rao, S., and Arora, A. (2011). Climate change impact assessment of water resources of India. Curr. Sci. 101, 356-371. Available online at: www. jstor.org/stable/24078515

IRAP (2015). Using technology to ensure groundwater safety and security in a tribal block of Maharashtra. Final report prepared by the Groundwater Survey and Development Agency, Pune and Institute for Resource Analysis and Policy (IRAP), Hyderabad in collaboration with UNICEF-Mumbai, India.

James, A. J., Kumar, M. D., Batchelor, J., Batchelor, C., Bassi, N., Choudhary, J., et al. (2015). Catchment assessment and planning for watershed managementvolume I, main report. The World Bank, Washington DC, US.

Khan, S. A., Kumar, S., Hussain, M. Z., and Kalra, N. (2009). "Climate change, climate variability and Indian agriculture: impacts vulnerability and adaptation strategies," in Climate Change and Crops, ed M. N. Bolotnikova (Berlin, Heidelberg: Springer), 19-38. doi: 10.1007/978-3-540-88246-6_2

Konapala, G., Mishra, A. K., Wada, Y., and Mann, M. E. (2020). Climate change will affect global water availability through compounding changes in seasonal precipitation and evaporation. Nat. Commun. 11, 1-10. doi: 10.1038/s41467-020-16757-w

Kumar, M. D. (2005). Impact of electricity prices and volumetric water allocation on energy and groundwater demand management: analysis from Western India. Energy Policy 33, 39-51. doi: 10.1016/S0301-4215(03)00196-4

Kumar, M. D. (2006). Water management in river basin: A case study of Sabarmati River basin in Gujarat. Ph. D Thesis submitted to the Department of Business Studies, Sardar Patel University, VV Nagar, Gujarat.

Kumar, M. D. (2010). Managing Water in River Basins: Hydrology, Economics, and Institutions. New Delhi: Oxford University Press. doi: 10.1093/acprof:oso/9780198065364.001.0001 management for improved climate resilience in Chhattisgarh part of Mahanadi river basin, in 2017, which is available at http://cgclimatechange.com/wp-content/uploads/2019/05/

WRM-Full-Report-V1-min.pdf.

Kumar, M. D., and Bassi, N. (2017). Water resource management for improved climate resilience in Chhattisgarh part of Mahanadi river basin. Final Report submitted to the Action for Climate Today, Oxford Policy Management Limited, New Delhi, India.

Kumar, M. D., Kabir, Y., Hemani, R., and Bassi, N. (2021). Management of Irrigation and Water Supply Under Climatic Extremes: Empirical Analysis and Policy Lessons From India. Basel: Springer Nature, Switzerland. doi: 10.1007/978-3-030-59459-6

Kumar, M. D., Ratna, V. R., and James, A. J. (2019). From Catchment Management to Managing River Basins: Science, Technology Choices, Institutions and Policy. Amsterdam: Elsevier Science, Netherlands.

Kumar, M. D., Scott, C. A., and Singh, O. P. (2011). Inducing the shift from flatrate or free agricultural power to metered supply: Implications for groundwater depletion and power sector viability in India. J. Hydrol. 409, 382-394. doi: 10.1016/j.jhydrol.2011.08.033

Kumar, M. D., Scott, C. A., and Singh, O. P. (2013). Can India raise agricultural productivity while reducing groundwater and energy use?. Int. J. Water Resour. Dev. 29, 557-573. doi: 10.1080/07900627.2012.743957

Kumar, M. D., and van Dam, J. C. (2013). Drivers of change in agricultural water productivity and its improvement at basin scale in developing economies. Water Int. 38, 312-325. doi: 10.1080/02508060.2013.793572

Mall, R. K., Singh, R., Gupta, A., Srinivasan, G., and Rathore, L. S. (2006). Impact of climate change on Indian agriculture: a review. Clim. Change 78, 445-478. doi: 10.1007/s10584-005-9042-x

Marengo, J. A., and Espinoza, J. C. (2016). Extreme seasonal droughts and floods in Amazonia: causes, trends and impacts. Int. J. Climatol. 36, 1033-1050. doi: $10.1002 /$ joc. 4420

Pallas, P. (1986). Water for animals. Land and Water Development Division, Food and Agriculture Organization of the United Nations, Rome, Italy.

Rosegrant, M. W., and Binswanger, H. P. (1994). Markets in tradable water rights: Potential for efficiency gains in developing country water resource allocation. World Dev. 22, 1613-1625. doi: 10.1016/0305-750X(94)00075-1

Rosegrant, M. W., and Gazmuri, S. R. (1994). Reforming water allocation policy through markets in tradable water rights: lessons from Chile, Mexico, and California. Cuadernos de Economía 32, 291-315.

Shen, D., and Wu, J. (2017). State of the art review: water pricing reform in China. Int. J. Water Resou. Dev. 33, 198-232. doi: 10.1080/07900627.2016.1171743

Singh, R. B., and Kumar, A. (2015). Climate variability and water resource scarcity in drylands of Rajasthan, India. Geoenviron. Disaster 2, 1-10. doi: 10.1186/s40677-015-0018-5

Smith, M. (1992). CROPWAT: A computer program for irrigation planning and management. Paper No. 46. Food and Agriculture Organization of the United Nations, Rome, Italy.

Xiong, W., Holman, I., Lin, E., Conway, D., Jiang, J., Xu, Y., et al. (2010). Climate change, water availability and future cereal production in China. Agric. Ecosyst. Environ. 135, 58-69. doi: 10.1016/j.agee.2009.08.015

Zhang, J., Li, D., Li, L., and Deng, W. (2013). Decadal variability of droughts and floods in the Yellow River basin during the last five centuries and relations with the North Atlantic SST. Int. J. Climatol. 33, 3217-3228. doi: 10.1002/joc.3662

Conflict of Interest: The authors declare that the research was conducted in the absence of any commercial or financial relationships that could be construed as a potential conflict of interest.

Copyright (c) 2021 Kumar and Bassi. This is an open-access article distributed under the terms of the Creative Commons Attribution License (CC BY). The use, distribution or reproduction in other forums is permitted, provided the original author(s) and the copyright owner(s) are credited and that the original publication in this journal is cited, in accordance with accepted academic practice. No use, distribution or reproduction is permitted which does not comply with these terms. 